\title{
State Cooperation with the International Criminal Tribunal for Rwanda
}

\author{
Cedric Ryngaert \\ Associate Professor of International Law, Leuven University; Leuven, Belgium \\ Utrecht University, Utrecht, The Netherlands
}

\begin{abstract}
This contribution discusses the mismatch between States' duties to cooperate with the International Criminal Tribunal for Rwanda (ICTR) and the reality of State non-cooperation. It focuses on two issues of cooperation which have been particularly important to the Tribunal: the arrest of fugitives by States, and the referral of cases to national jurisdictions under the Tribunal's completion strategy. The articles demonstrates how Rwanda has used cooperation which it knows is indispensable for the Tribunal's functioning - as a bargaining chip to obtain certain concessions from the Tribunal, but argues that also the ICTR itself and the international community should receive a portion of the blame for State non-cooperation.
\end{abstract}

\section{Keywords}

state cooperation; International Criminal Tribunal for Rwanda (ICTR); case referrals; arrest; Security Council

Pursuant to Article 28 of the Statute of the International Criminal Tribunal for Rwanda (ICTR), 'States shall cooperate with the [ICTR] in the investigation and prosecution of persons accused of committing serious violations of international humanitarian law' and 'States shall comply without undue delay with any request for assistance or an order issued by a Trial Chamber.' Thus, in hardly ambiguous terms, the ICTR Statute requires all States to cooperate with the ICTR. ${ }^{2}$ If States fail to cooperate with the ICTR, in accordance with Rule 7 bis of the ICTR Rules of Procedure and Evidence (RPE), the Trial Chamber or a Judge may request the President of the Tribunal to report the matter to the Security Council, or the Prosecutor may request the President to notify the Security Council.

In reality, States have not scrupulously complied with their statutory obligation to cooperate with the Tribunal. But never has the Tribunal referred a case of noncooperation to the Security Council, apparently out of fear of deterring State

1) Article 28(1) and (2) ICTR Statute (emphasis added).

2) The binding effect of this provision finds its legal roots in UN Security Council Resolution 955 (1994), which established the ICTR, and was adopted under Chapter VII of the UN Charter. 
cooperation. ${ }^{3}$ Instead, the ICTR has typically attempted to solve problems of State cooperation through diplomatic channels. This has not always been successful. In his excellent book on the subject, Victor Peskin describes how Rwanda - the State with which the ICTR has had the bulk of cooperation problems - has consistently managed to counter-shame the Tribunal (by besmirching the Tribunal's record), if attention was drawn to Rwanda's lack of cooperation (e.g., regarding the travel of defense witnesses or the production of documents). ${ }^{4}$ As a result, Rwanda could often get away with blatant violations of its duty to cooperate with the Tribunal, or used the threat of non-cooperation to cajole the Tribunal into taking decisions favourable to Rwanda.

We will not repeat Peskin's analysis of the 'virtual trials of cooperation' between Rwanda and the ICTR here. Nor will we analyze the legal minutiae of State cooperation regarding the production of documents or the summoning of witnesses; Charmaine de los Reyes has provided a very fine overview of ICTR case-law regarding these issues and has usefully drawn attention to the difficulties which the Defense faces in having documents produced by States or having witnesses travel from States. ${ }^{5}$ Instead, apart from discussing the Barayagwiza case, which cannot be dispensed with given its status as a classic case of successful Rwandan blackmailing of the Tribunal (Section 2), we will focus on two issues of cooperation which are particularly important to the Tribunal: the arrest of fugitives by States (Section 1) and the referral of cases to national jurisdictions under the Tribunal's completion strategy (Section 3). In a 2011 report to the Security Council, the ICTR President identified these issues of cooperation as the most pressing, alongside the transfer of convicts for the enforcement of their sentence, and the relocation of acquitted persons and persons who have served their sentence. ${ }^{6}$

\section{Arrests ${ }^{7}$}

International criminal tribunals, and the ICTR is no exception, do not have the power of arrest: to obtain custody of indicted persons, they are dependent on

3) Charmaine de los Reyes, 'State Cooperation and its Challenges for the International Criminal Tribunal for Rwanda', in Emmanuel Decaux, Adama Dieng and Malick Sow (eds.), From Human Rights to International Criminal Law / Des droits de l'homme au droit international pénal (Nijhoff, Leiden, 2007) 55, 80.

4) Victor Peskin, International Justice in Rwanda and the Balkans: Virtual Trials and the Struggle for State Cooperation (Cambridge University Press, Cambridge, 2008) 179.

5) Reyes, supra note 3 .

6) Report on the completion strategy of the International Criminal Tribunal for Rwanda (as of 12 May 2011), UN Doc. S/2011/317, para. 59 .

7) As far as Sections 1 and 2 are concerned, the author has drawn on his previous work, but has added updates. See Cedric Ryngaert, 'The International Prosecutor: Arrest and Detention', in 
States. Under the ICTR régime, as already noted in the introduction, States have a duty to cooperate with the ICTR, including with its requests for arrest and surrender. Despite the binding character of the ICTR Statute in this respect, State cooperation regarding arrest has not always been forthcoming - not so much from Rwanda, but mainly from other States. Many génocidaires had fled from Rwanda to neighbouring African States after Paul Kagame's Rwandan Patriotic Front (RPF) took power. Many of those States dragged their feet after receiving requests for arrest and surrender from the ICTR, because either they had been on friendly terms with the previous Rwandan regime or they lacked the resources to track and arrest the fugitives.

Kenya and Zaire/Democratic Republic of Congo (DRC) in particular failed to cooperate satisfactorily, ${ }^{8}$ a problem that had not yet fully been remedied by 2011 . In a 2011 progress report on its completion strategy, the ICTR called again on the DRC and Kenya to support the ICTR in tracking and arresting fugitives, and denounced a Kenya/ICTR joint task force for failing to make effective progress in tracking fugitives. ${ }^{9}$ Cooperation from Kenya, which supported the genocidal Hutu regime, has indeed come in fits and starts. A major Kenyan police operation (operation NAKI) managed to locate seven indicted persons, among whom the former Rwanda prime minister, in Nairobi in 1997, but this happened only after a tracking team set up at the ICTR had located them - which in turn convinced the Great Powers to exert pressure on Kenya. By and large, however, the relative pacification of the Great Lakes region has had a beneficial effect on the number of arrests of ICTR fugitives in the region..$^{10}$ Still, as of 2012 nine individuals remained on the run from the ICTR. ${ }^{11}$ One of them, Félicien Kabuga, one of the masterminds of the

Luc Reydams, Jan Wouters, Cedric Ryngaert (eds.), The International Prosecutor from Nuremberg to The Hague (Oxford University Press, Oxford, 2012) 647-699.

8) See Kingsley C. Moghalu, Rwanda's Genocide: The Politics of Global Justice (Palgrave Macmillan, New York, 2005), 161-165.

9) Report on the completion strategy of the International Criminal Tribunal for Rwanda (as of 12 May 2011), supra note 6, paras. 54-56.

10) Steven D. Roper and Lilian A. Barria, 'State Co-operation and International Criminal Court Bargaining Influence in the Arrest and the Surrender of Suspects', 21 Leiden Journal of International Law (2008) 457, 461. As recently as 30 June 2010, for instance, Jean Uwinkindi was arrested in Uganda. Uwinkindi would become the first individual to be referred to Rwanda under Rule 11 bis of the ICTR Rules of Procedure and Evidence (see below).

11) Also the international community's interest in tracking down the remaining Rwanda génocidaires in the Great Lakes region after 2002 (when the international community's attention shifted more towards the events in the Middle East, Iraq and Afghanistan, and the war on terror) is partly to blame for the lacklustre cooperation with the ICTR regarding arrest and surrender. Cf. Moghalu, supra note 8, 174. U.S. President Obama's decision in October 2011 to send U.S. military advisers to Uganda to help battle the Lord's Resistance Army, and arrest its leaders, may however signal renewed international interest in the region. See White House, Letter from the President to Congress, 14 October 2011. 
Rwandan genocide and according to Forbes Magazine one of the ten most wanted man on earth, ${ }^{12}$ is believed to be (still) hiding in Kenya.

Because few ICTR fugitives were present on Rwandan soil, few cooperation problems concerning arrest arose in the ICTR-Rwanda relationship. However, quite soon, the ICTR and Rwanda collided with each other in a case where they both wanted to have a fugitive present abroad arrested and surrendered: the Karamira case. Theoretically, the ICTR (unlike the ICC) has primacy over national courts. ${ }^{13}$ This implies that the international tribunal may formally request States to defer to the competence of the tribunal. ${ }^{14}$ Requested States are under an obligation to comply with the request of the tribunal. ${ }^{15}$ Accordingly, when a State has received a request for surrender from the ICTR and an extradition request from another State, such as Rwanda, it should honour the former request. The Karamira case has shown, however, that, in practice, the primacy of the ICTR may be a paper tiger only. Karamira was amongst those believed to be most responsible for the 1994 Rwanda genocide. After the atrocities, he had fled to India, where he was tracked down by Rwandan agents in 1996. During his transit to Rwanda at the Ethiopian airport of Addis Ababa, he fled. The Ethiopian police managed to immediately re-arrest him, but the publicity that had been given to the case lifted the veil of secrecy in which the transfer of Karamira was cloaked: ${ }^{16}$ upon learning of Karamira's presence in Ethiopia, the ICTR Prosecutor swiftly acted to request his surrender to the ICTR. This caused particular headaches for the Ethiopian Government, which was a political ally of the new Rwandan regime, and had apparently offered Rwanda transit through Ethiopia to move Karamira to Rwanda. Like in the case of Barayagwiza (see below), Rwanda thereupon started to apply pressure on the ICTR Prosecutor, threatening to no longer cooperate with the ICTR (e.g., the ICTR would no longer have access to witnesses in Rwanda). The pressure was so fierce that the OTP eventually decided to give in: Ethiopia transferred Karamira to Kigali rather than Arusha. He was executed in Rwanda in 1998.17

The Karamira case teaches us that blackmail by States competing with the tribunal for the surrender of an individual may well work: in case threats by the competing State may put the very functioning of the tribunal at risk, there may be no other option for the tribunal than to waive its right of primacy over national

\footnotetext{
12) See for this list: http://www.forbes.com/2011/o6/14/most-wanted-fugitives_slide_9.html.

13) Article 8.2 of the ICTR Statute.

14) Ibid.

15) Article 28 of the ICTR Statute.

16) Other secret Rwanda transfers were successful, however, such as the kidnapping of the former Rwandan minister of Justice in Zambia. Cf. Thierry Cruvellier, Le tribunal des vaincus (Calmann-Lévy, Paris, 2006) 28.

17) Ibid., 25-33.
} 
courts. ${ }^{18}$ The ICTR Prosecutor had to balance the different interests involved, also with an eye on the future and legacy of the court. At times, it could withstand State pressure - as is illustrated by the transfer of Colonel Bagosora from Cameroon to the ICTR in the face of intense Rwandan pressure $-{ }^{19}$ but at other times, as is illustrated by Karamira, caving in to pressure was apparently the only viable option for the Prosecutor.

It is noted, of course, that Rwanda presents a rather unique situation. The genocidal government had been deposed by the RPF, which had formed a new regime intent on bringing the former regime to justice. In most situations, the State on whose territory the atrocities occurred will not be interested in prosecuting the culprits, rather on the contrary (e.g., Serbia). It is not excluded, however, that such a State will, in spite of not being interested in genuine prosecution, request extradition, for the sole purpose of shielding the person from international prosecution. Obviously, in this situation, the requested State may be exposed to international criticism when extraditing the person to the requesting State rather than to the international tribunal. The lack of international protest against Karamira's transfer to Rwanda instead of to the ICTR was, in the final analysis, informed by the knowledge that Rwanda would truly mete out justice (the harsh manner in which justice was eventually meted out was taken for granted), although it may also have been attributable to the accommodative stance of the major powers towards the 'victimized' Rwandan Tutsi regime.

\section{Barayagwiza}

Many problems of cooperation between the ICTR and Rwanda have their roots in Rwanda's perception that the ICTR does not dispense justice. Rwanda, and Rwandan victims' groups, have often threatened to suspend, or have actually suspended, cooperation with the tribunal when they did not agree with ICTR proceedings (e.g., regarding witness protection), or with the outcomes of ICTR trials. Such problems arose at various junctures in history, but the 1998-1999 Barayagwiza saga can probably be considered as the lowest point in the ICTR-Rwanda relationship. The ICTR has hardly forgotten this experience: ${ }^{20}$ in the 2008 Munyakazi decision, the ICTR Referral Chamber cited the reaction of Rwanda to the ICTR's

18) Cf. the statement of Prosecutor Richard Goldstone in this sense, quoted in Cruvellier, supra note 16,31 .

19) Peskin, supra note 4 , at 172-177.

20) Contra William A. Schabas, in André Klip \& Göran Sluiter (eds.), Annotated Leading Cases of International Criminal Tribunals (Antwerp, Intersentia, Vol. VI) p. 262 ('It is perhaps significant that the final Barayagwiza decision of the Appeals Chamber of 3 November 1999, seems to have been entirely forgotten in subsequent case law, as if it were a bad dream.'). 
decisions in Barayagwiza as evidence of the absence of sufficient guarantees against outside pressures in Rwanda. ${ }^{21}$ This in turn informed its decision not to refer the Munyakazi case to Rwanda (as will be set out in more detail below, the ICTR has now started referring cases to Rwanda, however, citing progress regarding fair trial guarantees).

Barayagwiza was transferred from Cameroon to the ICTR on 19 November 1997, nineteen months after his initial detention on 17 April 1996 by Cameroon at the request of the ICTR. Upon arrival at the detention unit of the ICTR, a ninety-sixday interval elapsed before he made his initial appearance on 23 February 1998. The delays appeared at least partly attributable to the ICTR. Believing that his rights were violated, Barayagwiza filed a habeas corpus-like motion with the Court, which was dismissed by the Trial Chamber (1998). ${ }^{22}$ But on appeal (1999), the Appeals Chamber ruled that the case was so egregious as to warrant a remedy under the abuse of process doctrine because of 'the combination of delays that seemed to occur at virtually every stage of the Appellant's case.'. ${ }^{23}$ Thus, in the tribunal's view, it was the cumulative character of the violations of the OTP in relation to Barayagwiza's arrest and detention that led to a finding of abuse of process. The tribunal observed starkly that 'the Appellant was simply forgotten about.' ${ }^{24}$ Citing the duty of prosecutorial diligence, it concluded that the Prosecutor failed in her duty to take the steps necessary to have the Appellant transferred in a timely fashion,, ${ }^{25}$ and that, in addition, she should have taken prudent steps so as to ensure that "the accused is brought before a Trial Chamber "without delay" upon his transfer to the Tribunal. ${ }^{26}$ The Appeals Chamber then ordered the most extreme possible measure to remedy the prosecutorial inaction and the resultant denial of Barayagwiza's rights: the release of the appellant and the dismissal of the charges against him. ${ }^{27}$

The release of Barayagwiza immediately caused serious political problems for the ICTR, since Rwanda - who wanted to see Barayagwiza convicted for the role

21) The Prosecutorv. YussufMunyakazi, Case No. ICTR-97-36-Rubis, Decision on the Prosecutor's Request for Referral of Case to the Republic of Rwanda, 28 May 2008, para. 40 (" $[\mathrm{T}]$ he Chamber is of the view that sufficient guarantees against outside pressures are lacking in Rwanda. In particular, the Chamber notes the Rwandan Government's interrupted cooperation with the Tribunal following a dismissal of an indictment and release of an Appellant [Prosecutor $v$. Barayagwiza, Case No. ICTR-97-19, Appeal Chamber, Decision, 3 November 1999] as well as its negative reaction to foreign judges for indicting former members of the Rwandan Patriotic Front ("RPF") [footnote omitted]. The Chamber is concerned that these actions by the Rwandan Government, as will be explained in more detail below, show a tendency to pressure the judiciary, a pressure against which a judge sitting alone would be particularly susceptible.').

22) Trial Chamber, Barayagwiza, ICTR-97-19-AR72, Decision of 17 November 1998.

23) Appeals Chamber, Barayagwiza I, ICTR-97-19-AR72, 3 November 1999, para. 109.

24) Ibid., para. 96 .

25) Ibid., para. 98.

26) Ibid., para. 99 .

27) Ibid. 
he played in the 1994 genocide - announced the suspension of all cooperation with the tribunal until the Chamber would reverse its decision: Rwanda barred the ICTR Prosecutor from her office in Kigali, and denied permission to leave the country to sixteen witnesses scheduled to testify in the trial of Bagilishema at the ICTR. ${ }^{28}$ From then onwards, politics took over. ${ }^{29}$ Pressure mounted on the Tribunal to reconsider its ruling. ${ }^{30}$ In its pleadings before the Appeals Chamber, the ICTR Prosecutor did not shy away from highlighting the political dimension of the Bayaragwiza case: in her characteristically blunt style, in the face of an imminent shutdown of the ICTR, she urged the Appeals Chamber to give in to Rwanda and reconsider its earlier ruling: ${ }^{31}$

Let me just say a few words with respect to the government of Rwanda. The government of Rwanda reacted very seriously in a tough manner to the decision of 3 November 1999 . It was a politically motivated decision, which is understandable. It can only be understood if one is cognisant with the situation, if one is aware of what happened in Rwanda in 1994. I also notice that, well, it was the Prosecutor that had no visa to travel to Rwanda. It was the Prosecutor who was unable to go to her office in Kigali. It was the Prosecutor who could not be received by the Rwandan authorities. In November, after your decision, there was no co-operation, no collaboration with the office of the Prosecutor. In other words, justice, as dispensed by this Tribunal was paralysed and it was the trial of Bagilishima which had to be adjourned because the Rwandan government did not allow 16 witnesses to appear before this Court. In other words, they were not allowed to leave the territory of Rwanda. [...] However, your Honours, due account has to be taken of that fact. Whether we want it or not, we must come to terms with the fact that our ability to continue with our prosecution and investigations depend on the government of Rwanda. That is the reality that we face. What is the reality? Either Barayagwiza can be tried by this Tribunal, in the alternative; or the only other solution that you have is for Barayagwiza to be handed over to the state of Rwanda to his natural judge, judex naturalis.

Otherwise I am afraid, as we say in Italian, possiamo chiudere la baracca. In other words we can as well put the key to that door, close the door and then open that of the prison. And in that case the Rwandan government will not be involved in any manner..."

Given the political importance of the case, on 31 March 2000, the Appeals Chamber rendered a new decision, which, not wholly surprisingly, reversed the 1999 decision. Observing 'that the violations suffered by the Appellant and the omissions of the Prosecutor are not the same as those which emerged from the facts on which the [1999] Decision is founded', the Chamber ordered that the initial remedy - the dismissal of the indictment and the release of the appellant,

28) Munyakazi, supra note 21, para. 41; Peskin, supra note 4, 179.

29) See also at length Moghalu, supra note 8, 111-123.

30) Peskin points out in this respect that '[ICTR Prosecutor] Del Ponte remained in Arusha for two weeks until the Appeals Chamber announced its decision to hold a hearing to reconsider its initial ruling.' Peskin, supra note 4181.

31) See Prosecutor v. Barayagwiza, Case No. ICTR-97-19-AR72, Appeals Chamber, Decision: Prosecutor's Request for Review or Reconsideration", 31 March 2000, Declaration of Judge Raphael Nieto-Navia, para. 2. See also Munyakazi, supra note 21, para. 41. 
must be altered: ${ }^{32}$ if he were found not guilty, he would receive financial compensation, and if he were found guilty, his sentence would be reduced. ${ }^{33}$

As expected, the Appeals Chamber's second decision was severely criticized: the 'new' facts identified by the Chamber were actually known to the Prosecutor (the moving party), ${ }^{34}$ and the decision was thus considered to be politically inspired. ${ }^{35}$ Nonetheless, criticism was also levelled at the Appeals Chamber's first decision, ${ }^{36}$ so that, in the final analysis, the second decision may well represent good law.

The Barayagwiza episode demonstrated that the Tribunal does not operate in a political vacuum. After Barayagwiza, both the Prosecutor and the Chambers realized that they should tread cautiously so as not to antagonize Rwanda, whose cooperation with the Tribunal was indispensable. This also meant not applying the law on State cooperation to its fullest extent, e.g., by not seeking a referral to the UN Security Council in case of Rwandan-non-cooperation. As Charmaine de los Reyes observed in this respect: 'As the [ICTR] applies the rules to secure State cooperation, it risks attracting politically motivated embargos on assistance as well as criticism regarding its impartiality.'37 That being said, obviously, the ICTR organs will almost never openly admit that they do not function independently and have succumbed to sustained political pressure in the face of potential noncooperation by Rwanda. ${ }^{38}$

32) Appeals Chamber, Barayagwiza II, ICTR-97-19-AR72, 31 March 20oo, para. 74.

33) Ibid., para. 75. See also the ICTR's judgment in Prosecutorv. Nahimana, Barayagwiza, Ngeze, ICTR-99-52-T, 3 December 2003, para. 1107 (reducing Barayagwiza's sentence to thirty-five years of imprisonment).

34) E.g., Schabas, supra note 20, 261-262.

35) Cf. Peskin, supra note 4, 184 (noting that 'among many ICTR staff members, doubts emerged about the autonomy of the tribunal from Rwandan pressure').

36) A tribunal judge interviewed by Peskin, ibid., 180, confided that ' $[\mathrm{i}] \mathrm{f}$ you have these kinds of allegations, I don't see how you can let [Barayagwiza] walk away on a technicality ... You can't just let him walk away, that's not justice.. Another tribunal judge, interviewed by Peskin, ibid., 184 , also stated that it is inadvisable to render 'a legal decision that is wrong in the reality of the world'. Smeulers, an academic commentator, has deemed it 'unacceptable that such a man gets off the hook because of perceived small procedural mistakes ...' (Alette Smeulers, in André Klip and Göran Sluiter (eds.), Annotated Leading Cases of International Criminal Tribunals (Intersentia, Antwerp, Vol. XI) 111). Schabas, for his part, has observed that the judges 'found themselves adopting a position that was simply too extreme, too shrill, entirely disproportionate ... the remedy proposed, namely a permanent stay of proceedings, was quite excessive ... The 3 November 1999 decision was quite simply bad law, and the Appeals Chamber had to do something to fix it.' (Schabas, supra note 20, 261-262). And Swart has commented that 'the violations of the Appellant's rights, although serious, were considerably less egregious and numerous than the Appeals Chamber believed' (Bert Swart, in André Klip and Göran Sluiter (eds.), Annotated Leading Cases of International Criminal Tribunals, (Intersentia, Antwerp, Vol. II) 206). 37) Reyes, supra note 3, 55 .

38) Barayagwiza II, supra note 32, para. 34 (" in a tough manner to the decision of 3 November 1999." Later, the Attorney General of Rwanda appearing as representative of the Rwandan Government, in his submissions as 'amicus curiae' to the Appeals Chamber, openly threatened the non co-operation of the peoples of Rwanda 


\section{Case Referrals to States under Rule nbis}

One may gather from the above-mentioned account of Rwandan cooperation with the ICTR, that the Tribunal has adopted a particularly - and perhaps overly - accommodative stance towards Rwanda. However, accommodation was not, at least not initially, the strategy espoused by the ICTR Trial Chamber when it decided on the Prosecutor's requests for referral to Rwanda, under Rule 11 bis of the Tribunal's Rules of Procedure and Evidence, of various cases pending before the ICTR: these requests were dismissed on the ground that the rule of law quality of Rwanda's justice system was insufficient. Only in 2011, with the closure of the ICTR imminent, did an ICTR Referral Chamber refer the first case to Rwanda (Uwinkindi).

The Prosecutor's referral policy implemented the ICTR completion strategy and hinged on the ability and willingness of States to cooperate with the ICTR in bringing intermediate- and lower-rank ICTR accused to trial in national jurisdiction. State acceptance of referred ICTR cases is an important, although non-obligatory, aspect of State cooperation with the ICTR, and warrants a detailed discussion, all the more so given the recent evolutions in ICTR case-law.

\subsection{Early Attempts at Referral to Third States (2005-2007)}

In 2003, the UN Security Council urged the ICTR to formalize a completion strategy which would involve the transfer of 'cases involving intermediate- and lowerrank accused to competent national jurisdictions, as appropriate, including Rwanda, in order to allow the ICTR to achieve its objective of completing investigations by the end of 2004, all trial activities at first instance by the end of 2008, and all of its work in 2010.39 To allow the transfer of such cases as part of its completion strategy, the ICTR judges (as did their ICTY counterparts) added Rule 11bis to the ICTR Rules of Procedure and Evidence. ${ }^{40}$

with the Tribunal if faced with an unfavourable Decision by the Appeals Chamber on the Motion for Review. The Appeals Chamber wishes to stress that the Tribunal is an independent body, whose decisions are based solely on justice and law. If its decision in any case should be followed by non-cooperation, that consequence would be a matter for the Security Council.'). See however the ICTR Prosecutor pleadings in Barayagwiza, quoted above.

39) Eighth Preambular Paragraph of Security Council Resolution 1503 (2003). See also para. 6 of Security Council Resolution 1534 (2004), requesting the Tribunal 'to provide the Council, by 31 May 2004 and every six months thereafter, assessments by its President and Prosecutor, setting out in detail the progress made towards implementation of the Completion Strategy of the Tribunal, explaining what measures have been taken to implement the Completion Strategy and what measures remain to be taken, including the transfer of cases involving intermediate and lower rank accused to competent national jurisdictions'.

40) Rule 11 bis RPE: Referral of the Indictment to another court: 
On the basis of Rule 11 bis, from 2005 onwards the Prosecutor filed requests with the ICTR Trial Chambers to refer a number of cases, initially not to Rwanda, but to other States that were willing to try the accused under the universality principle. While it appeared logical to send the cases to Rwanda - the State where the atrocities had occurred - the Prosecutor pointed out that Rwanda still imposed the death penalty and could not guarantee a fair trial; as a result, the requirements of Rule 11bis (C) would not be met in the Prosecutor's view. ${ }^{41}$ But interestingly, the Prosecutor added that, even if those requirements were met, 'strong public policy reasons favour the involvement of other countries in the prosecution of the Accused because it would be a manner of educating people in other countries on the lessons to be learned from the Rwandan genocide and would promote the development of ideas to prevent future similar tragedies. ${ }^{42}$ Accordingly, prosecuting Rwandan génocidaires was considered as a joint endeavour of the ICTR and the entire community of States, even if the latter had no nexus with the Rwandan genocide. ${ }^{43}$

This ideal of a joint endeavour was however short-lived. Only France, Norway and the Netherlands declared themselves able and willing to take over ICTR cases. Ultimately, the Trial Chambers only granted the Prosecutor's request for a referral of two cases to France (Bucyibaruta and Munyeshyaka, 2007), ${ }^{44}$ and even then, as

'(A) If an indictment has been confirmed, whether or not the accused is in the custody of the Tribunal, the President may designate a Trial Chamber which shall determine whether the case should be referred to the authorities of a State:

(i) in whose territory the crime was committed; or

(ii) in which the accused was arrested; or

(iii) having jurisdiction and being willing and adequately prepared to accept such a case, so that those authorities should forthwith refer the case to the appropriate court for trial within that State.

(B) The Trial Chamber may order such referral proprio motu or at the request of the Prosecutor, after having given to the Prosecutor and, where the accused is in the custody of the Tribunal, the accused, the opportunity to be heard.'

$[\ldots]$

41) Rule 11 bis (C): 'In determining whether to refer the case in accordance with paragraph (A), the Trial Chamber shall satisfy itself that the accused will receive a fair trial in the courts of the State concerned and that the death penalty will not be imposed or carried out.'

42) The Prosecutorv. Michel Bagaragaza, Case No. ICTR-2005-86-Rubis, 19 May 2006.

43) Even before 2005, however, States had exercised universal jurisdiction over Rwandan génocidaires who were not indicted by the ICTR. See Luc Reydams, 'Belgium's First Application of Universal Jurisdiction - the "Butare Four" case', 1 Journal of International Criminal Justice (2003) 428. Other States, such as the Netherlands, found that they did not have jurisdiction over crimes of genocide committed in Rwanda in 1994. See Cedric Ryngaert, 'Universal Jurisdiction over Genocide and Wartime Torture in Dutch Courts: an Appraisal of the Afghan and Rwandan cases (2007)', 2 Hague Justice Journal (2007:2) 13.

44) The Prosecutor v. Laurent Bucyibaruta, Case No. ICTR-2005-85-I, Decision on Prosecutor's request for referral of indictment to France, 20 November 2007; The Prosecutor $v$. Wenceslas Munyeshayaka, Case No. ICTR-2005-87-I, Decision on Prosecutor's request for referral of indictment to France, 20 November 2007. 
of 2011, France had not made notable progress regarding the prosecution of these cases. $^{45}$ The Prosecutor's request for a referral of the Bagaragaza case to Norway was declined on the grounds that Norway did not have jurisdiction ratione materiae over the crimes charged (genocide, conspiracy to commit genocide, and complicity in genocide).$^{46}$ The Prosecutor thereupon filed a request for a referral of the same case to the Netherlands, which was granted by the Trial Chamber ${ }^{47}$ - but then, when push came to shove, Dutch courts, hearing the referred case, ruled that they did not have jurisdiction to hear the case. A brief discussion of the Dutch proceedings in the Bagaragaza case is warranted as it illustrates well the difficulties plaguing the ICTR's referral policy to 'third' States. ${ }^{48}$

At first instance, in 2007, a Dutch District Court found that Dutch courts could not entertain 'original' or 'derivative' jurisdiction over the case of Bagaragaza. In the Court's view, original jurisdiction did not lie since, at the time of the Rwandan genocide in 1994, Dutch law did not provide for universal jurisdiction over genocide. The Court observed that such universal jurisdiction may now apply pursuant to the Dutch International Crimes Act of 2003, but it added that such new legislation cannot apply retroactively, nor can customary international law (provided that it allowed the exercise of universal jurisdiction over genocide back in 1994) custom being an unwritten source of law - expand the jurisdictional rules of the Dutch code. Derivative jurisdiction, in the sense of jurisdiction derived from the jurisdiction of the ICTR over the case, did not lie either, according to the Court. In order for Dutch law to be applicable to persons against whom the prosecution has been transferred from a foreign State to the Netherlands, a treaty is required pursuant to Article 4a of the Dutch Penal Code. Applying the criteria listed in the provision to the case of Bagaragaza, the Court ruled that, while the ICTR could be equated with a foreign State (if a functional interpretation of the legal provision were espoused), no treaty that listed arrangements for the transfer of cases from the ICTR to the Netherlands could be identified. The criteria of the said Article 4a were therefore not met, and the Dutch Prosecutor's request regarding Bagaragaza was held to be inadmissible. ${ }^{49}$

45) See Statement by Justice Hassan B. Jallow, Prosecutor of the ICTR, to the United Nations Security Council, 6 June 2011 ('I am also hopeful that the two other cases referred to France (Laurent Bucyibaruta and Wenceslas Munyeshaka) will receive greater attention in the course of this year in the French courts.').

46) The Prosecutor v. Michel Bagaragaza, Case No. ICTR-2005-86-Rubis, Decision on the Prosecution motion for referral to the Kingdom of Norway, para. 16. Norway had stated that it would lay charges against the accused under the domestic law of homicide, which did however not require the specific intent of genocide.

47) The Prosecutor v. Michel Bagaragaza, Case No. ICTR-2005-86-Rubis, Decision on the Prosecution motion for referral to the Kingdom of the Netherlands, 13 April 2007.

48) The author draws on a previous note he published as 'The Failed Referral of Michel Bagaragaza from the ICTR to the Netherlands', 4 Hague Justice Journal (2009) 237-243.

49) The reasoning of the District Court is reprinted in the Supreme Court judgment in Bagaragaza, LJN: BD6568, Hoge Raad, o8/oo142, Section 5.1. 
On appeal, in late 2007, the Appeals Court upheld the inadmissibility of the case, yet it did so on other grounds. It concurred with the District Court's finding that there was no treaty between the ICTR and the Netherlands in the sense of Article 4a of the Penal Code. In this context, the Court held, relying on an expert advisory opinion, that the correspondence between the Prosecutor of the ICTR and the Dutch Minister of Justice relating to the transfer of Bagaragaza could be qualified as an informal treaty, but that such an informal treaty was not contemplated by the drafters of the Penal Code amendment resulting in Article 4a of the Penal Code. ${ }^{50}$ The Appeals Court's decision differed from the District Court's decision, however, in that it refused to equate the ICTR with a State for purposes of Article 4a, thereby rejecting the District Court's flexible, teleological statutory interpretation: the Court pointed out that equating an organ of the United Nations (the ICTR, established by the UN Security Council) did not satisfy the requirement of cognizability (kenbaarheid) of the law. ${ }^{51}$ On this point, the Supreme Court added that the terminological distinction between a 'State' and an 'international tribunal' was commonly accepted, and that accordingly there was no reason to construe 'State' as also implying 'international tribunal.'52

After the District Court of The Hague had held that it did not have jurisdiction over the acts committed by Bagaragaza, the ICTR swiftly revoked its transfer order on 17 August 2007. Bagaragaza himself was subsequently transferred, on 20 May 2008, to the ICTR, where, on 24 June 2008, he pleaded guilty with the Prosecutor. After Bagaragaza's transfer to Arusha, the Dutch Supreme Court (Hoge Raad) eventually upheld the Court of Appeals's decision on 21 October 2008. The ICTR convicted Bagaragaza to 8 years' imprisonment on 17 November $2009 .{ }^{53}$

The Dutch courts' inflexible application of Dutch criminal procedure law on judicial cooperation may appear regrettable. This sort of legal nicety indeed seriously compromises the ICTR's completion strategy. Jurisdictional and substantive obstacles to a successful prosecution in the State to which cases are referred under Rule 11 bis render referrals problematic, and oblige the ICTR, which struggles which a huge caseload anyway, to again take up cases which it could possibly have gotten rid of. Dutch courts should not come in for too much criticism, however. After all, they simply applied Dutch law, and as is common in criminal

50) The reasoning of the Appeals Court is reprinted in the Supreme Court judgment, Section 5.2, para. 29.

51) Id., para. 16. The Appeals Court argument relating to the presence/absence of a treaty for purposes of Article 4a of the Penal Code appears superfluous, as the criteria of Article 4a are cumulative. If the transferring entity is not a State, Article 4a cannot come into play anymore, irrespective of the 'treaty' condition being fulfilled. Nevertheless, the argument was apparently made in the interest of the law.

52) Supreme Court judgment, Section 6.5.1.

53) The Prosecutor v. Michel Bagaragaza, Case No. ICTR-05-86-S, Sentencing Judgment, 17 November 2009. 
cases, rather strictly. ${ }^{54}$ Those who are really to blame for the failing Completion Strategy resulting from the aborted Rule 11 bis referrals are those who devised and implemented the completion strategy in the first place: the United Nations and the ICTR. The Dutch Appeals Court in Bagaragaza observed incisively in this respect that it might have reached a different conclusion if the United Nations and the Netherlands had entered into a treaty which would have clarified the transfer of cases of ICTR indictees to the Netherlands in the framework of the completion strategy, even in situations where the Netherlands did not have original jurisdiction. ${ }^{55}$ Such a treaty would have satisfied the requirements of Article 4 a of the Dutch Penal Code, and have allowed for a smooth transfer of ICTR cases to the Netherlands. The Bagaragaza saga shows that the architects of the ICTR Completion Strategy paid insufficient attention to the legal details of its implementation.

\subsection{The Attempts to Refer Cases to Rwanda}

The Prosecutor, realizing that the route of referring cases to third States may prove to be a dead end, changed course rather early on, in 2007, when it started filing requests (five in 2007) for case referrals to Rwanda. ${ }^{56}$ The Prosecutor had come round to believing that the accused would receive a fair trial in the courts of Rwanda, and that the death penalty would not be imposed or carried out.

54) A cynic may contend that the Dutch courts' rigid interpretation of the statute was informed by policy considerations rather than accepted techniques of statutory interpretation. The courts may have been concerned about Dutch judicial authorities being overburdened by cases which bear almost no relation with the Netherlands. The Dutch Government's acceptance of the ICTR Prosecutor's request to have Bagaragaza's case transferred to the Netherlands, and its reasoning that the transfer was covered by Article $4 \mathrm{a}$ of the Penal Code, appears to belie this, however.

55) Appeals Court judgment, reprinted in Supreme Court judgment, Section 5.2, para. 29.

56) The Prosecutor's Request for the Referral of the Case of Gaspard Kanyarukiga to Rwanda Pursuant to Rule 11 bis of the Tribunal's Rules of Procedure and Evidence, 7 September 2007 (below referred to as the "Prosecution Request"); The Prosecutor $v$. Fulgence Kayishema, The Prosecutor's Request for the Referral of the Case of Fulgence Kayishema to Rwanda Pursuant to Rule 11 bis of the Tribunal's Rules of Procedure and Evidence, 11 June 2007; The Prosecutor $v$. Yussuf Munyakazi, The Prosecutor's Request for the Referral of the Case of Yussef Munyakazi to Rwanda Pursuant to Rule 11 bis of the Tribunal's Rules of Procedure and Evidence, 7 September 2007; The Prosecutor v. Idelphonse Hategekimana, The Prosecutor's Request for the Referral of the Case of Idelphonse Hategekimana to Rwanda Pursuant to Rule 11 bis of the Tribunal's Rules of Procedure and Evidence, 7 September 2007; The Prosecutor v. Jean-Baptiste Gatete, The Prosecutor's Request for the Referral of the Case of Jean-Baptiste Gatete to Rwanda Pursuant to Rule 11 bis of the Tribunal's Rules of Procedure and Evidence, 28 November 2007.

See also Statement by Justice Hassan B. Jallow, Prosecutor of the ICTR, to the United Nations Security Council, 6 December 2010 ('Referral of all but three of the ten fugitives to national jurisdictions for trial remains a key element of the completion strategy of the ICTR. In the absence of acceptance of these cases by other member states, Rwanda continues to be the focus of the ICTR referral strategy.'). 
The efforts of the Prosecutor were however swiftly rebuffed by the Trial Chambers, which, in a string of judgments rendered in 2008, refused to honour the Prosecutor's requests for referrals on the ground that Rwandan courts failed to live up to adequate due process standards. ${ }^{57}$ The Chambers held in particular that the accused would face difficulties in calling witnesses residing outside Rwanda and obtaining witnesses residing in Rwanda because they would be afraid to testify before Rwandan courts. They added that a conviction to life imprisonment could mean solitary confinement in violation of international detention standards, and that Rwanda's legal framework may not criminalize command responsibility. ${ }^{58}$ In so doing, the Trial Chambers passed harsh judgment on the quality of the Rwandan court system, and appeared to set the ICTR again on a collision course with Rwanda. This occurred at as crucial a time as the end of the ICTR's lifespan: without referrals of a substantial number of cases on its docket to States, and Rwanda in particular, the ICTR would face serious difficulties in terminating its trials on time. The ICTY, in contrast, had been quite successful in referring cases back to the States where the atrocities had taken place, and thus seemed set to meet the targets set in its completion strategy. ${ }^{59}$ Therefore, the ICTR Prosecutor stated ominously in a December 2010 statement at the UN Security Council:

In the absence of a transfer of these cases and with the probable arrest of fugitives in the near future, the work of the Tribunal could increase significantly, thus extending the projected completion date for trials. The transfer of such a workload to the proposed residual mechanism would expand the size of such an interim institution substantially. On the other hand the referral of these cases now to national jurisdictions could possibly see the end of trials at the Tribunal by the end of 2011. ${ }^{60}$

To avert the danger of the ICTR not meeting the completion deadline, the Prosecutor did not relent in his efforts to have genocide cases tried in Rwanda. He handed over to Rwanda the case files of 25 suspects who had been investigated

57) See at length on these decisions: Inge Onsea, 'The Legacy of the ICTR in Rwanda in the Context of the Completion Strategy: The Impact of Rule 11bis', in Cedric Ryngaert (ed.), The Effectiveness of International Criminal Justice (Intersentia, Antwerp, 2009) 173-194.

58) The Prosecutorv. Yussuf Munyakazi, Case No. ICTR-97-36-Rubis, Decision on the Prosecutor's request for referral of case to Rwanda, 28 May 2008; The Prosecutor v. Jean-Baptiste Gatete, Case No. ICTR-200o-61-Rubis, Decision on Prosecutor's Request for Referral to the Republic of Rwanda, 17 November 2008; The Prosecutorv. Ildephonse Hategekimana, Case No. ICTR-00-55BRubis, Decision on Prosecutor's Request for Referral to the Republic of Rwanda, 18 June 2008; The Prosecutor v. Fulgence Kayishema, Case No. ICTR-01-67-Rubis, Decision on Prosecutor's Request for Referral to the Republic of Rwanda, 16 December 2008; The Prosecutor v. Kanyarukiga, Case No. ICTR-2002-78-R11bis, Decision on Prosecutor's Request for Referral to the Republic of Rwanda, 6 June 2008.

59) Cf. Jens Dieckmann and Christina Kerll, 'UN Ad Hoc Tribunals Under Time Pressure Completion Strategy and Referral Practice of the ICTY and ICTR from the Perspective of the Defence', 8 International Criminal Law Review (2008) 87.

60) Statement by Justice Hassan B. Jallow, Prosecutor of the ICTR, to the United Nations Security Council, 6 December 2010. 
but not indicted by the ICTR (and thus did not qualify for the Rule 11 bis referrals) in $2010,{ }^{61}$ and - encouraged by the following dictum of the Trial Chamber in the Munyakazi referral case - he continued to engage with Rwanda regarding the referrals:

The Chamber would like to emphasise that it has taken notice of the positive steps taken by Rwanda to facilitate referral. The Chamber is of the view that if Rwanda continues along this path, the Tribunal will hopefully be able to refer future cases to Rwandan courts. ${ }^{62}$

And indeed, Rwanda took steps with a view to meeting the concerns voiced by the Trial Chambers in the negative referral decisions of 2008, in particular concerning the insufficiency of witness protection (the imposition of the death penalty or life imprisonment with special conditions was no longer an issue). ${ }^{63}$ In 2010, the Prosecutor took the view that the changes brought about by Rwanda satisfied the criteria of Rule 11 bis as construed by the Trial Chambers. Again entering into a judicial alliance with Rwanda, it filed a request for the referral of the Uwinkindi case to Rwanda. ${ }^{64}$ Various non-governmental organizations swiftly countered the Prosecutor's positive characterization of legal reform in Rwanda by filing amicus curiae briefs with the Trial Chamber. ${ }^{65}$ The Government of Rwanda and the Kigali Bar Association supported the referral.

In a decision rendered on 28 June 2011, that must have surprised many an observer, the ICTR Trial Chamber ordered the case of Uwinkindi to be referred to Rwanda, citing, indeed, the progress made by Rwanda. ${ }^{66}$ Any progress, however,

61) Report of the International Criminal Tribunal for Rwanda to UNGA (2010), UN Doc. A/65/188-S/2010/408, para. 53 .

62) The Prosecutorv. Yussuf Munyakazi, Case No. ICTR-97-36-Rubis, Decision on the Prosecutor's request for referral of case to Rwanda, 28 May 2008, para. 67 .

63) Prosecutor v. Jean Uwinkindi, Case No. ICTR-2001-75-Rubis, Decision on the Prosecutor's request for referral of case to Rwanda, 28 June 2011, para. 47.

64) Prosecutor v. Jean Uwinkindi, Case No. ICTR-2001-75-R11bis, Prosecutor's request for the referral of the case of Jean-Bosco Uwinkindi to Rwanda pursuant to Rule 11bis of the Tribunal's Rules of Procedure and Evidence ("Motion"), 4 November 2010. Jean Uwikindi, an indicted fugitive, was arrested in Uganda on 30 June 2010 and transferred to the Tribunal on 2 July 2010.

65) Human Rights Watch, International Criminal Defence Attorneys Association, the International Association of Democratic Lawyers. See Prosecutor v. Jean Uwinkindi, Case No. ICTR-2001-75-Rubis, Decision on Prosecutor's request for referral to the Republic of Rwanda, 28 June 2011, paras. 7-14.

66) Id., para. 223 ('This Chamber notes that, in the intervening period, Rwanda has made material changes in its laws and has indicated its capacity and willingness to prosecute cases referred by this Tribunal. This gives the Referral Chamber confidence that the case of the Accused, if referred, will be prosecuted consistent with internationally recognised fair trial standards enshrined in the Statute of this Tribunal and other human rights instruments.'). This decision was confirmed on appeal by the ICTR Appeals Chamber, which did not find an error of law in the Trial Chamber's reasoning. Jean Uwinkindi, Case No. ICTR-01-75-ARubis, Decision on Uwinkindi's appeal against the referral of his case to Rwanda and related motions, 16 December 2011. 
was often merely made on paper, as a number of amici pointed out. This was not lost on the Chamber, but it observed that the issues which concerned the previous Referral Chambers 'had been addressed to some satisfaction' by Rwanda. ${ }^{67}$ As becomes clear throughout the decision, the Chamber was willing to take risks when referring cases to Rwanda, whose legal system still left to be desired, and which had only taken some steps to remedy the defects identified in the 2008 (non-)referral decisions. ${ }^{68}$ In a later referral decision of June 6th, 2012, in the case of Munyagishari, the Referral Chamber was somewhat more cautious, however. ${ }^{69}$ While in principle ordering the transfer of this case to Rwanda, the Chamber nevertheless imposed a number of conditions, relating to the monitoring process, the assignment of a lawyer, and the protection of defense witnesses, to be met by Rwanda before the case could also practically be referred. ${ }^{70}$ This may be seen as a minor correction of the Uwinkindi referral decision. This decision may, in particular as far as the monitoring of referred cases was concerned, have been taken too hastily: the Referral Chamber appeared to accept at face value that the African Commission on Human and People's Rights (ACPHR) would be willing to send court monitors to Rwanda. ${ }^{71}$ In reality, however, as of April 2012, no agreement with the ACPHR or another suitable organization had materialized, as a result of which the President of the ICTR had to issue a decision instructing the appointment of two ICTR legal staff as interim monitors (April $5^{\text {th }}$, 2012). Only after this decision could Uwinkindi be transferred to Rwanda (April $\left.19^{\text {th }}, 2012\right) .{ }^{72}$ Negotiations with the ACPHR were still on-going as of June 2012; only after an agreement has been reached, will Munyagishari be transferred, provided that the other conditions imposed by the Chamber are met. ${ }^{73}$

\footnotetext{
67) Id., para. 224 (emphasis added).

68) See, e.g., paras. $96,102,103,146$.

69) The Prosecutor v. Bernard Munyagishari, Case No. ICTR-2005-89-Rubis, Decision on Prosecutor's request for referral to the Republic of Rwanda, 6 June 2012.

70) Id., para. 220 (emphasizing 'that it is persuaded to refer this case only subject to the conditions that an independent organisation is appointed as monitor before, or shortly after the transfer of the Accused; the President of the Kigali Bar Association confirms to the President of the Tribunal that the Accused will be assigned a lawyer with previous international experience and the Prosecutor General of Rwanda provides a written Assurance satisfying the President of the Tribunal or the Residual Mechanism that witnesses who testify in the present case and who are then compelled to testify in subsequent domestic genocide cases shall not risk prosecution that would otherwise be prohibited by the Transfer Law as an indirect consequence of appearing as witnesses in this transfer case.').

71) Note that Rule 11bis D(iv) of the ICTR RPE was amended to enable not only the Prosecutor to appoint monitors, but also to enable the Chambers to request the Registrar to send observers, even observers of another institution (the African Commission) (para. 209).

72) Id., para. 211.

73) Id., para. 220.
} 


\subsection{Assessing the Referrals to Rwanda}

Especially the Uwinkindi referral decision, and Munyagishari to a lesser extent, have - again - been a major judicial victory for Rwanda in its tug-of-war with the ICTR. Unless the quality of the rule of law in Rwanda is drastically reduced, it is expected that the Trial Chambers will soon refer even more cases involving low- or mid-level perpetrators to Rwanda, ${ }^{74}$ while the chances that the ICTR will ever consider revocation are low, as the Chamber noted itself in the Uwinkindi case. ${ }^{75}$ The decision will also please the ICTR's political overlords at the UN Security Council, who would like to have the ICTR terminate its mandate as agreed. In fact, the Trial Chamber seems to be informed by this political imperative, where, unlike in 2008, it assesses Rwanda's legal practice with a particularly light touch. ${ }^{76}$

When reading the decision, sometimes it appears that the referral was a foregone conclusion for which ex post some legal arguments had to be found. In practical terms, referral decisions can be considered as faits accomplis. It is striking in this respect that the Referral Chamber, in the last paragraph of its decisions in Uwinkindi and Munyagishari, 'expresses its solemn hope that the Republic of Rwanda, in accepting its first referral from this Tribunal, will actualise in practice the commitments it has made in its filings about its good faith, capacity and willingness to enforce the highest standards of international justice in the referred cases. ${ }^{77}$ Although this hope would be underpinned by the existence of ACPHR trial monitors - who would provide 'robust monitoring' - and the possibility of

74) In early 2012, two cases concerning two accused still at large were referred to Rwanda: The Prosecutor v. Fulgence Kayishema, Case No. ICTR-01-67-Rubis, Decision on the Prosecutor's request for referral of case to Rwanda, 22 February 2012; The Prosecutor v. Charles Sikubwabo, Case No. ICTR-95-1D, Decision on the Prosecutor's request for referral of case to Rwanda, 26 March 2012. It is noted that the Uwinkindi decision has not henceforth made referrals automatic. A referral decision continues to be based on the merits of each case. See Munyagishari referral decision, para. 41 ('The Chamber is obligated by Rule 11 bis to satisfy itself that Munyagishari, specifically, will receive a fair trial in the courts of Rwanda. The referral of one accused does not necessitate that all subsequent requests under Rule 11 bis must be automatically granted. The facts pertaining to each request vary and the Chamber shall consider the merits of the Accused's arguments, particularly those that have not previously been advanced. Nonetheless, the Chamber is bound by the Appeals Chamber interpretation of the law.') (citation omitted).

75) Uwinkindi referral, para. 217 ('the Referral Chamber will only consider the revocation mechanism as a remedy of last resort'). See also Munyagishari referral, para. 216. Rule 11bis E provides for revocation: 'At any time after an order has been issued pursuant to this Rule and before the accused is found guilty or acquitted by a court in the State concerned, the Trial Chamber may proprio motu or at the request of the Prosecutor and upon having given to the authorities of the State concerned the opportunity to be heard, revoke the order and make a formal request for deferral within the terms of Rule 10.'

76) Id., para. 90 ('the Chamber recalls that its role is not to assess whether the fears of the individual potential witnesses are legitimate or not'); para. 103 ('relevant Rwandan laws must be given a chance to operate before being held to be defective').

77) Id., para. 225. See also Munyagishari referral, para. 222 (emphasis added). 
the revocation of the accused's referral, ${ }^{78}$ one cannot fail to note the sense of surrender which the Referral Chamber's words ooze. Without credible sanctions, one can only - almost helplessly - hope that Rwanda lives up to the expectation that defense counsel or witness will not be prosecuted for contempt or perjury when making statements amounting to a denial of genocide, that no measures of retaliation are taken against defense witnesses, and that the courts will function independently and impartially. ${ }^{79}$

That being said, one may want to give the Referral Chamber credit for its recent referrals, as it seems to have departed from its previous stringent requirement that Rwanda have fully developed rule of law safeguards in place at the time of the prosecutor's application for referral. One may indeed wonder whether it is reasonable that an international criminal tribunal providing a high degree of rule of law protection, based on Western conceptions of the rule of law, should require exactly the same guarantees, to be realized here and now, from a country in transition, such as Rwanda. Arguably, an imperfect rule of law should pass the test, as this would allow for democratic learning (it is indeed hoped that in Uwinkindi and Munyagishari Rwanda will truly implement its commitments), and allows trials to take place in the very territory where the atrocities took place, thereby encouraging local ownership and contributing to national reconciliation. Viewed from this perspective, the Trial Chamber's decision in Uwinkindi should not, or at least not in the first place, be viewed as caving in to Rwandan pressure or as a hurried political decision informed by the ticking clock of the tribunal's completion strategy.

Nonetheless, more ethnographically oriented authors such as Nicola Palmer believe that even in Uwinkindi (and one would assume, afortiori, in Munyagishari), the ICTR has relied too heavily on its own understanding of rule of law standards (and the understanding of international NGOs) instead of 'critically engaging with concurrent judicial practice inside [Rwanda].80 Palmer argues, on the basis of semi-structured interviews which she conducted with various protagonists at the ICTR and Rwanda, that ICTR judges are mainly interested in the development of the tribunal's own body of legally consistent case-law, whereas Rwandan legal practitioners rather emphasize the building of judicial capacity. ${ }^{81}$ It is precisely the difference between these objectives that informs the ICTR Rule 11 bis referrals

78) Uwinkindi referral, paras. 207-217. See on 'robust monitoring' Munyagishari referral, para. 211.

79) In this respect, 'Rwanda has expressed its intention to introduce new legislation that would allow the panel for any case referred for trial in Rwanda to include judges from foreign or international courts. The Chamber expects this to happen upon referral of this case and finds that this measure would further enhance the Accused's fair trial rights.' Id., para. 114 .

80) Nicola Palmer, 'Transfer or Transformation?: a Review of the Rule 11 bis Decisions of the International Criminal Tribunal for Rwanda', in 20 African Journal of International and Comparative Law (2012) 1, 20.

81) Id., at 7-16. 
vaudeville, with the Tribunal since 2007 requiring that Rwanda push through legal reforms before any case could be referred, Rwanda obeying, and the Tribunal subsequently requesting new reforms. The conditions imposed by the Tribunal in Munyagishari clearly fit this mould, although it remains no less true that by nevertheless ordering the transfer of cases in both Uwinkindi and Munyagishari, the Tribunal has taken a leap of faith in Rwanda's rule of law potential, as compared to the pre-2011 decisions that simply dismissed the Prosecutor's applications for referral to Rwanda.

Having evaluated the ICTR referrals to Rwanda, let us now briefly return to the initial idea of referring cases to third States (see section 3.2). As the Prosecutor now seems to have secured the referral of cases to Rwanda, will he still pursue negotiations with third States (in particular European States) to accept cases from trial from the ICTR? ${ }^{82}$ As discussed earlier, such referrals have not been particularly successful in the past. But in addition, the willingness of European States to accept these cases may have diminished. Recent practice regarding alleged Rwandan perpetrators who were not indicted by the ICTR shows that European governments are hardly enthusiastic about trying Rwandan génocidaires in their own courts. ${ }^{83}$ The Swedish government, for instance, decided to extradite a Rwandan (Ahorugeze) to Rwanda who had been arrested in Stockholm in 2008. ${ }^{84}$ Admittedly, European courts have so far refused to extradite individuals to Rwanda, citing exactly the due process concerns cited by the ICTR Referral Chambers in 2008. ${ }^{85}$ However, the Referral Chamber's decision in the Uwinkindi decision may give fresh ammunition to governments to convince their courts to grant

82) See Statement by Justice Hassan B. Jallow, Prosecutor of the ICTR, to the United Nations Security Council, 6 June 2011 ('In a further attempt to implement the referral strategy of the ICTR and whilst continuing our focus in Rwanda, I visited a number of European states in April this year and held discussions with senior officials to encourage their governments to consider accepting cases for trial from the ICTR. I wish to record my appreciation for the warm reception by the member states concerned. I sincerely look forward to their positive consideration of our requests.').

83) But see the conviction of François Bazaramba in a Finnish court in 2010. Rwanda had requested Finland to extradite Bazaramba, but Finland refused to honour the request on the grounds that the defendant might not be assured of a fair trial there. Finland subsequently went on to try Bazaramba. See International Justice Tribune (IJT 108), 16 June 2010.

84) The Swedish Supreme Court ruled on 26 May 2009 that the Swedish Government had final authority to grant the extradition of Rwandan nationals. The Court dismissed the arguments of Ahorugeze that he was in danger of persecution in Rwanda, or that his fair trial rights would be violated. The decision (in Swedish) is available at http://www.haguejusticeportal.net/Docs/ NLP/Sweden/Ahorugeze_SupremeCourt_26-5-2009.pdf.

85) See, e.g., $R$ (Brown) v. Governor of Belmarsh Prison (DC) [2007] 2 WLR; Vincent Brown and others v. the Government of Rwanda and the Secretary of State for the Home Department [2009] EWHC 770 (Admin) (ruling that there was a 'real risk' that the individuals would suffer a 'flagrant denial of justice by reason of their likely inability to adduce the evidence of supporting witnesses' if they were extradited to Rwanda, and fearing interference in the judiciary by the government of Rwanda). 
extradition to Rwanda, ${ }^{86}$ and to clear their docket of Rwandan genocide cases. This policy has been bolstered even further by the 2011 decision of the European Court of Human Rights in the already mentioned case of Ahorugeze. In this decision, the Court relied heavily on the ICTR Trial Chamber's considerations in the Uwinkindi case, and considered itself unable to conclude that substantial grounds existed for believing that Ahorugeze, if extradited to stand trial in Rwanda, faces a real risk of treatment proscribed by Article 3 or would face a real risk of a flagrant denial of justice' in violation of Article 6 ECHR. ${ }^{87}$

Ultimately, if the goal of the completion strategy is to prevent impunity, it does not really matter where presumed perpetrators of the Rwandan genocide are tried. What is relevant is that they are tried somewhere, whether it is at the ICTR, in Rwanda, or in Europe. If Rwanda is willing to try them all, impunity is certain not to ensue, all the more so because Rwanda considers presumed génocidaires as enemies of the State who will not get away with a lenient sentence. However, the fact that Rwanda precisely treats those individuals as such is reason for concern: will Rwanda sufficiently protect their due process rights? The ICTR has given Rwanda the benefit of the doubt, and it will now be up to the monitors of the African Human Rights Commission to remove all remaining doubts in the years to come. But then, if the Commission attests to rights violations, it remains to be seen what remedies can realistically be pursued. In the past, Rwanda has demonstrated abundantly its capacity to deflect criticism of its own behaviour by drawing attention to the failures of the ICTR, and by highlighting the shameful role (or absence of any role) of the Western powers in the Rwandan genocide. As far as the failures of the ICTR are concerned, the extremely long duration of the ICTR trial in the recently finished Government case may be cited. In this case, a judgment was rendered only on 30 September 2011 after a trial of eight years. This trial, which even resulted in the acquittal of two accused who were in custody since 1999, is sure to raise eyebrows in Kigali and further undermine the ICTR's image in Rwanda. Reflecting on this case, Schabas has even gone as far as to state that 'the Rwandan justice system compares well to the International Tribunal in this

86) Note however that the Referral Chamber in Uwinkindi, para. 43, has held that 'the nature of extradition and referral proceedings is materially different': 'Extradition is a bilateral arrangement between two States wherein upon extradition the extraditing State transfers the custody of the accused to the receiving State and the former exercises no control over the trial of the extradited person. Referral, however, is a suigeneris mechanism wherein the referring Tribunal retains the power to revoke its decision if fair trial rights are not ensured. Referral is also ordered pursuant to a stringent monitoring mechanism that keeps the Tribunal informed of the receiving State's adherence to the conditions of referral.' It is not fully clear, however, whether this fine legal distinction should have consequences for State-to-State transfer cases. After all, the human rights concerns that may impede referral are exactly the same concerns that may impede extradition.

87) ECtHR, Ahorugeze v. Sweden, Appl. No. 37075/o9, Judgment of 27 October 2011, paras. 95 and 129 . 
respect: ${ }^{\prime 8}$ As far as the failures of Western powers are concerned, it is of note that a Belgian judge recently attributed (December 2010) the evacuation of a UN compound where Rwandans had taken refuge in the early days of the genocide, to Belgium, and found a causal link between the evacuation and the subsequent death of the Rwandans at the hands of the Interahamwe militia. ${ }^{89}$ Realizing their own mistakes, the international community will quite possibly refrain from voicing fierce criticism of Rwanda's trial record in the referred cases, let alone calling for a revocation by the ICTR. In fact, referrals, as well as extraditions, to Rwanda appear as faits accomplis.

\section{Concluding Observations}

This contribution has described the mismatch between States' duties to cooperate with the ICTR and the reality of State non-cooperation. States have a statutory obligation to cooperate with the Tribunal when it comes to locating and arresting fugitives, allowing witnesses to travel freely to the ICTR, or handing over documents to the Tribunal. In addition, they have at least a moral duty to accept cases for referral from the ICTR in the framework of the Tribunal's completion strategy if their laws allow for genocide trials and comply with international human rights standards, and similar duties to offer detention facilities to enforce ICTR convicts' sentences and to help the Tribunal relocate acquitted persons who have served their sentence. Reality, however, shows that States have not always complied with these legal and moral obligations. Few States have offered to accept cases for referral, to enforce sentences or to relocate persons. Rwanda has even used cooperation - which it knows is indispensable for the Tribunal's functioning - as a bargaining chip to obtain certain concessions from the Tribunal.

That being said, the ICTR should not escape its fair share of criticism for the failures of cooperation between the Tribunal and States, Rwanda in particular. Peskin has for instance argued that ICTR Prosecutor Del Ponte should not have abandoned her plans to indict RPF officers, but instead should have used any leverage that she had to ensure international cooperation with these plans. ${ }^{90}$ More importantly perhaps, due to the slow pace of trials before the ICTR, and the Tribunal's failures during investigations, prosecutions, and trials, as exemplified by the Barayagwiza case, the Tribunal has lost the moral high-ground and made itself vulnerable to Rwandan counter-attacks of its record, consisting, inter alia, of

88) William A. Schabas, 'Justice Delayed at the International Criminal Tribunal for Rwanda', available at http://humanrightsdoctorate.blogspot.com/, 1 October 2011.

89) Court of First Instance (civil), Mukeshimana and others v. Belgian State and others, R.G. $\mathrm{n}^{\circ}$ 04/4807/A et 07/15547/A, ILDC 1604 BE 2010, 8 December 2010.

90) Peskin, supra note 4, 222-225. 
(unlawful) cooperation boycotts or boycott threats. Finally, apart from non-cooperative States and the ICTR itself, also the international community should receive a portion of the blame for State non-cooperation: the major powers - out of shame for the genocide or for strategic reasons - have failed to exert strong pressure on recalcitrant States (Rwanda in particular).

The end-goal of cooperation with the ICTR should however not allow for all possible means. This applies in particular to non-obligatory cooperation mechanisms, such as the referral of cases to national jurisdictions under Rule 11 bis RPE. In this respect, it is arguable that the international community, by imposing a very tight completion schedule on the ICTR, has contributed to a prosecutorial practice of requesting premature case referrals to States that were not able or willing to prosecute ICTR indictees. Whether the very first ICTR Trial Chamber referral of an ICTR case to Rwanda will prove to be premature remains to be seen, however. 